This PDF is a selection from an out-of-print volume from the National Bureau of Economic Research

Volume Title: Tax Policy and the Economy, Volume 12

Volume Author/Editor: James M. Poterba, editor

Volume Publisher: MIT Press

Volume URL: http://www.nber.org/books/pote98-1

Publication Date: January 1998

Chapter Title: Tax Incentives for Higher Education

Chapter Author: Caroline M. Hoxby

Chapter URL: http://www.nber.org/chapters/c10913

Chapter pages in book: (p. $49-82)$ 


\section{TAX INCENTIVES FOR HIGHER EDUCATION}

\section{Caroline M. Hoxby}

Harvard University and NBER

\section{EXECUTIVE SUMMARY}

In "Tax Incentives for Higher Education," Caroline Hoxby investigates the economic effects of provisions related to higher education in the Taxpayer Relief Act of 1997. This timely paper summarizes the major initiatives: Hope Tax Credits, Tax Credits for Lifelong Learning, Education IRAs, and tax deductibility of interest on student loans. The paper describes the incentives that these provisions generate for attending college and discusses the question of whether the people who most need to attend college are the ones most likely to be induced to attend by the new initiatives. It then synthesizes the existing literature on how federal government funds for higher education affect the tuition charged by colleges and universities, and it assesses the likely consequences of the new provisions for tuition. Finally, the paper discusses the probable effects of the initiatives on family saving and on the degree of effort and planning that students put into college.

\section{INTRODUCTION}

The Clinton Administration claimed that the 1998 budget represents the "biggest investment in higher education since the G.I. Bill 50 years ago." This statement is something of an exaggeration in that it is true in nominal dollars, but not in real dollars. Nevertheless, both Congress and the Administration were eager to "do something" for higher education this

The author is Morris Kahn Associate Professor of Economics, Harvard University, and Faculty Research Fellow, National Bureau of Economic Research. 
year, and they made it a centerpiece of the budget debate. The result was more than 40 billion dollars in tax expenditures related to higher education in the budgets for fiscal years 1998 through 2002.

In this paper, I analyze the tax initiatives related to higher education in the 1998 budget. I attempt to assess each of the major programs both as economic policy and as education policy. In the long run, the two criteria tend to boil down to a single one, since a policy that causes people to make more optimal investments in education is good for economic growth.

It is important to stress that higher-education initiatives should be analyzed with the goal of determining whether they induce people to invest in the amount of education that is optimal for them. ${ }^{1}$ All too often, analysis focuses purely on the narrow question of whether an initiative will increase enrollment in higher education. While enrollment estimates are primarily what is needed for federal budget projections, enrolling in college does not necessarily correspond to successful investment in college education. Among OECD (Organization for Economic Cooperation and Development) countries, the U.S. has the lowest rate of college completion conditional upon college enrollment. Moreover, the U.S. rate of college completion conditional upon enrollment has been falling steadily since the late 1960s, suggesting that there may even be a causal link between subsidies to higher education and the percentage of enrolled students who are prepared and able to complete a degree. For these reasons, it is best to treat enrollment as only one choice in the larger decision to invest in higher education and to analyze the effects of a higher education initiative on that larger decision, which includes issues related to students' choice of college, student effort and preparation, saving for college, student persistence, and the use of college as a signal of ability.

\section{HIGHER EDUCATION IN THE 1998 BUDGET}

Table 1 provides a brief summary of the items related to education in the 1998 budget. The two most costly items related to education are the tax credits called the Hope Credit and the Tax Credit for Lifelong Learning. Combined, these are expected to cost $\$ 31$ billion in fiscal years 1998 through 2002. The Hope Credit will subsidize an individual's first two years of undergraduate education by giving him a tax credit worth 100 percent of the first $\$ 1,000$ plus 50 percent of the second $\$ 1,000$ he spends

${ }^{1}$ Ideally, the standard should be whether an education investment is socially optimal. However, achieving privately optimal education investments would be the bulk of a process that achieved social optimality. 
TABLE 1

Provisions Related to Higher Education in the 1998-2002 Budgets

Program

Additional

$\operatorname{cost}\left(\$ 10^{9}\right)$

Pell grants:

Tuition, fee, and living assistance for poor students enrolled

in higher education; the maximum Pell grant raised from

$\$ 2,700$ to $\$ 3,000$.

Hope scholarship:

A $\$ 1,500$-a-year non-refundable tax credit for the first two years of college; credit is $100 \%$ of the first $\$ 1,000$ that a student spends on tuition and fees, and $50 \%$ of the second $\$ 1,000$; phases out for individuals earning $\$ 40,000$ to $\$ 50,000$ and couples earning $\$ 80,000$ to $\$ 100,000$ a year.

Tax credit for lifelong learning:

A non-refundable tax credit for undergraduate and graduate study; credit is worth $20 \%$ of up to $\$ 5,000$ a year spent on tuition and fees through 2002, and $20 \%$ of up to $\$ 10,000$ a year thereafter; same phaseout as Hope Scholarship.

Penalty-free IRA withdrawals for college expenses and taxsheltered college savings accounts:

In addition to penalty-free withdrawals from IRA accounts that are not counted as gross income so long as they pay for college expenses, families may contribute up to $\$ 500$ a year for each child into a savings account that has the same tax shelter as an IRA account and whose distributions are not counted as gross income if the proceeds are used to pay for college expenses; phases out for families earning $\$ 150,000$ to $\$ 160,000$ a year.

Deduction of student-loan interest:

Whether they itemize or not, borrowers may deduct from their taxable income the interest paid on student loans; deduction starts at $\$ 1,000$ a year in 1998 and rises in $\$ 500$ increments to $\$ 2,500$ by 2001; phases out for families earning $\$ 60,000$ to $\$ 75,000$ a year.

Minor tax expenditures related to higher education:

Exclusion from taxable income of value of outstanding loans forgiven for community service; exclusion from taxable income of up to $\$ 5,250$ a year in undergraduate tuition aid provided by employer. 
on tuition and fees for the first two years of college. Thus, the maximum Hope Credit is $\$ 1,500$ a year. The Hope Credit is a modified descendent of Georgia's "Hope Scholarship," which President Clinton first proposed in his State of the Union address.

The Tax Credit for Lifelong Learning can be used for any year of undergraduate or graduate education. It provides 20 percent of tuition and fees up to $\$ 5,000$ through 2002, and 20 percent of tuition and fees up to $\$ 10,000$ thereafter. The maximum tax credit is thus $\$ 1,000$ through 2002 and $\$ 2,000$ after 2002. Both the Hope Credit and the Tax Credit for Lifelong Learning are non-refundable and phase out for individuals (non-joint-filers) earning $\$ 40,000$ to $\$ 60,000$ a year or couples (joint filers) earning $\$ 80,000$ to $\$ 100,000$ a year. The Tax Credit for Lifelong Learning is what is left of the President's proposal for a middle-class tax deduction for college tuition of up to $\$ 10,000$ a year.

Penalty-free withdrawals from Individual Retirement Accounts (IRAs) to pay for college expenses are a policy that has been proposed perennially since the Bush administration. The 1998 budget will be the first to allow them. The standard 10-percent penalty will not apply to a withdrawal from an IRA that pays for college expenses. In addition, the 1998 budget provides for new, tax-sheltered college savings accounts called Education IRAs (EIRAs). EIRAs are similar to IRAs, except that the only expense for which they can be used without attracting a penalty is college expense. A family may contribute up to $\$ 500$ a year to an EIRA for each dependent child under the age of nineteen. The right to make penalty-free withdrawals from IRAs or contribute to tax-sheltered college savings accounts phases out for families (joint filers) earning $\$ 150,000$ to $\$ 160,000$ a year.

The other major tax expenditure for higher education in the 1998 budget is the tax deduction for interest paid on student loans. This is an above-the-line deduction, so whether or not they itemize, borrowers may deduct their interest up to $\$ 1,000$ in 1998 . The maximum deduction rises in $\$ 500$ increments to $\$ 2,500$ in 2001 . The tax deduction phases out for families (joint filers) earning $\$ 60,000$ to $\$ 75,000$ a year.

The 1998 budget also contains two minor tax expenditures for higher education. The first restores for three years the exemption that lets workers deduct from their taxable income up to $\$ 5,250$ a year in undergraduate tuition aid provided by their employers. This exemption is not available for graduate work and is therefore not a large budget item. The second excludes from a student's taxable income the value of outstanding institutional loans forgiven that year by a college in exchange for community service. This provision affects only a tiny share of students.

Finally, the 1998 budget raises the maximum Pell grant from $\$ 2,700$ a 
year to $\$ 3,000$ a year. The Pell grant pays tuition, fees, and some living expenses for poor students enrolled in college. The grant that each student receives is a function of his family's income, assets, and composition; the tuition, fees, and other expenses of his college; and the maximum Pell grant.

As for coordination among the higher-education initiatives, only one of the following four tax claims can be made for a student in a given year: distribution from an IRA or EIRA, deduction of interest paid on student loans, the Tax Credit for Lifelong Learning, and the Hope Credit. Any of the four claims can be combined with the Pell grant, so long as the relevant calculations of tuition paid subtract the amount paid by the Pell grant.

\section{THE HIGHER-EDUCATION ENVIRONMENT OF THE 1990s}

Before analyzing any of these initiatives, it is useful to survey the state of higher education in the 1990s. Particularly since the late 1970s, the behavior of both the demand side of higher education (the students) and the supply side (the colleges) has changed in major ways.

\subsection{Demand-Side Trends in Higher Education}

On the demand side, the single most important phenomenon has been the increased rate of return to education. A large empirical literature now documents the high rate of return to college, relative to history, over the entire period from 1978 to the present. ${ }^{2}$ The rate of return to college education appears to have been particularly high during the periods from 1978 to 1985 and from 1992 to the present. Relatively crude, but nationally representative, calculations based on the Current Population Survey (CPS) suggest that each year of college education earned a nominal rate of return of 5 percent from 1972 to 1978 , of 13 percent from 1978 to 1985, of 9 percent from 1986 to 1991, and of 11 percent from 1992 to $1996 .{ }^{3}$ Estimates based on the National Longitudinal Survey of Youth (NLSY) incorporate the tuition and fee costs of college (unlike the CPS) and control better for a student's family background and ability. These

2 Katz and Murphy (1992); Juhn, Murphy, and Pierce (1993); Murnane, Willett, and Levy (1995).

${ }^{3}$ Author's calculations based on wage differentials between 25-29-year-olds who have a baccalaureate degree and who have a high-school degree or the equivalent. The rewording of the education question makes the very recent path of this wage differential difficult to interpret. 
data are less representative but portray the same general trends: a 5percent rate of return for 1976 to 1978, a 9-percent rate of return from 1979 to 1984 , and a 7-percent rate of return from 1985 to 1987.4

Debate has arisen about whether the high rates of return actually represent increased returns to college or increased returns to ability, which is correlated with college. ${ }^{5}$ Perhaps the most convincing evidence comes from students' enrollment behavior. When the rate of return to college is high, students who are computing their optimal human-capital investment should increase their desired years of education. In fact, Figure 1 demonstrates that colleges' administrative records show a steady upward trend in the percentage of 18- to 24-year-olds who are enrolled in college education over the period. ${ }^{6}$ If every demographic group should have experienced the same growth in the percentage of young people who enroll in college, then enrollment growth has been slow for young people who are African-Americans, Hispanic, or from households below the 25 th percentile of the American income distribution. ${ }^{7}$ However, these groups began the period with substantially lower enrollment rates, and the percentage growth in their enrollment is approximately the same as that of non-minority, non-poor households. Cameron and Heckman (1997) present some well-estimated evidence on how these rates of return influenced college enrollment.

Two-year colleges accounted for 28 percent of total enrollment in 1978, but they have generated nearly half (44 percent) of the growth in college enrollment since that time. About 96 percent of two-year college enrollment takes place in public colleges. This, combined with the fact that the overall public college share of enrollment has remained constant at 78 percent, suggests that public two-year enrollment has been substituted for some public four-year college enrollment. Since the United States has a low rate of college completion for students enrolled in public four-year colleges, it is fair to summarize the environment as one in which students who have a public college education are likely to attain less than a baccalaureate degree while students who have a private college education are more likely to attain the baccalaureate degree.

Some analysts have blamed real increases in college costs for the fact that the four-year college completion rate has been falling since the late

\footnotetext{
4 Author's calculations based on the NLSY.

5 See Murnane, Willett, and Levy (1995) and Taber (1995).

6 Author's calculations based on the Integrated Postsecondary Education Data System (IPEDS) and Higher Education General Information System (HEGIS), compared with sample data on the population of 18- to 24-year-olds from the Current Population Survey.
}

7 See Kane (1997) for discussion. 

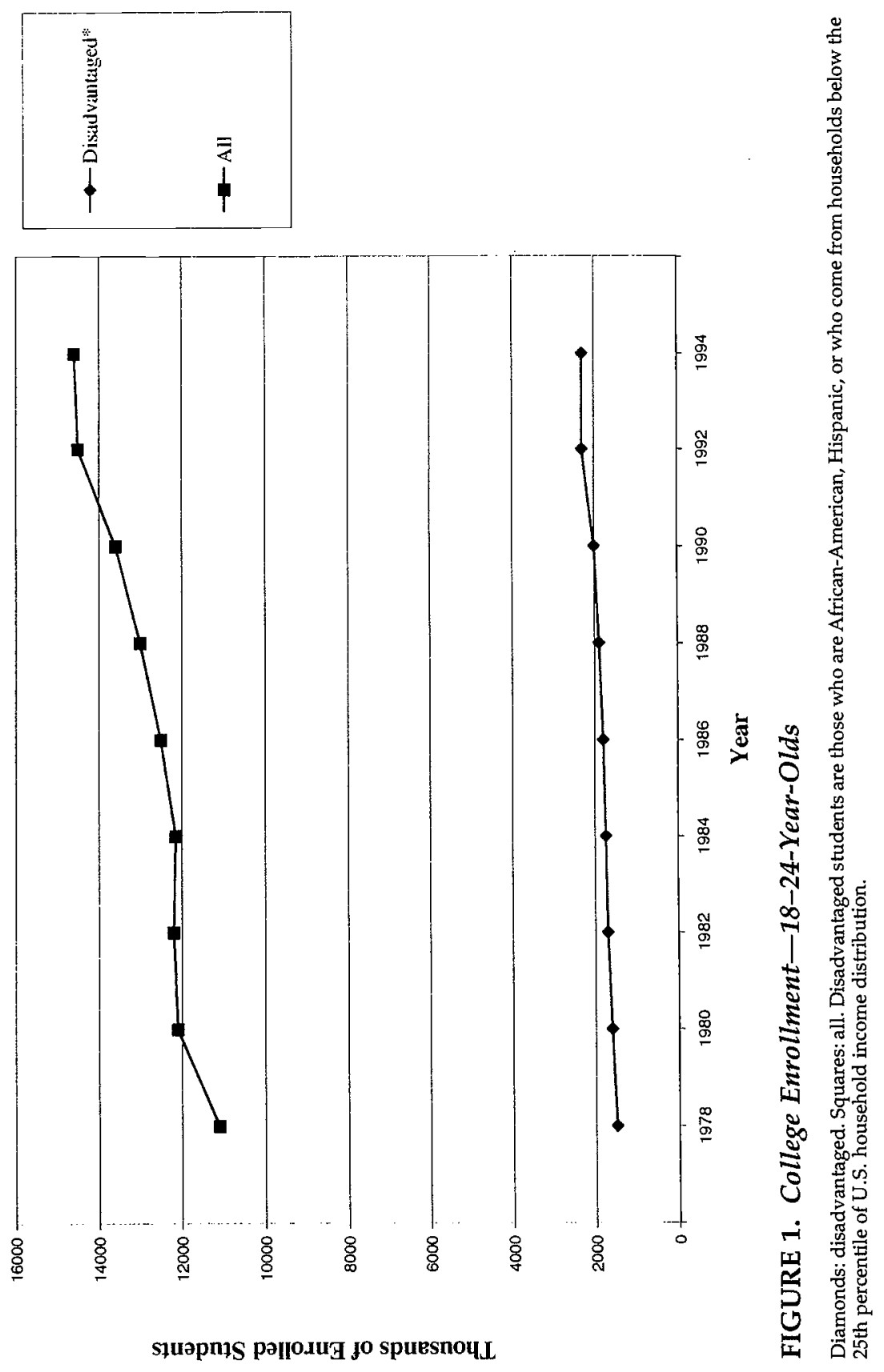
1960s. Rising financial hardship may explain a small share of students' increasing tendency to drop out, but this explanation generally has a poor fit with the data. The growth rate in the cost of the 44 percent of colleges that account for 90 percent of the students who complete less than four years has been less than one-quarter of the growth rate in the cost of the 56 percent of colleges that account for the remaining 10 percent. To account for the difference in the probability of dropping out between these two groups of colleges, the elasticity of dropping out with respect to the price would have to be almost twelve times as large for students in the first group of colleges as for students in the second group. Note that 87 percent of the first group of students are enrolled in public colleges, whereas only 24 percent of the second group of students are enrolled in public colleges. ${ }^{8}$

A better explanation than financial hardship for the rising noncompletion rate is that people who are unlikely to attain baccalaureate degrees-either because of their preferences or because of their aptitude-have increasingly been drawn into college. Several factors have been at work. One factor is students' increased use of college for remediation and language acquisition (see Breneman, 1997). Approximately 14 percent of all college students and 35 percent of minority students take at least one remedial class. If English as a second language is also counted as remedial, then the percentage of minorities who take at least one remedial class rises to 41 percent. Increasing remediation at the college level is not an indictment of the efficacy of college teaching. On the contrary, it is a symptom of America's troubled secondary education sector and of increased immigration.

Another factor drawing low-probability-of-completion students into college is the Pell grant. Use of the Pell grant has risen by 50 percent since 1978 (National Center for Education Statistics, 1996). Students who use the Pell grant at inexpensive (usually two-year) colleges need contribute very little to tuition. Under these circumstances, students have weak financial incentives to enter with the preparation they need or make the effort they need to make in order to derive maximal benefits from college. The fact that opportunity costs (forgone wages) are the main cost of college education for many students who use the Pell grant only makes it more likely that a student who realizes he is poorly prepared will decide to make very little effort in college. Pell grant students have only weak incentives to police their colleges and ensure that the colleges offer sufficient education for the tuition being charged (to the federal govern-

${ }^{8}$ All statistics in this paragraph are author's calculations based on CASPAR, a panel data set based on IPEDS and HEGIS. 
ment). Since the early 1980s, the General Accounting Office has been concerned about whether colleges admit students whom they do not intend to seriously educate, in order to gain access to their Pell grants. The use of the Pell grant in proprietary and private non-profit colleges has fallen since the mid-1980s, perhaps in response to increased scrutiny of these colleges. Public colleges, however, have always accounted for the vast majority of Pell grant enrollments, so whether Pell grants are used for low-return education at these public colleges is the weighty question.

A final feature of higher education's demand side is the implicit tax on asset accumulation due to need-based financial aid. The savings disincentives generated by need-based aid were pointed out by Feldstein (1995) and Edlin (1993), who demonstrated that colleges' granting less generous financial aid to families who have more savings (all else equal) generates a tax on saving. The best empirical evidence for this phenomenon is due to Kim (1997) and Dick and Edlin (1997). Estimates suggest that the savings disincentives almost exclusively affect families whose children attend private colleges and whose incomes exceed $\$ 60,000$. These families account for a small percentage of college enrollment but a high percentage of those whom we would ordinarily expect to save for college. Moreover, there is reason to think that families are generally saving too little for higher education. Students whose college admissions test scores and secondaryschool grades are similar should make similar human-capital investments in college. Yet, National Postsecondary Student Aid Survey data indicate that students with similar college aptitude make college choices that show excess sensitivity to family savings. The elasticity of tuition at the college chosen with respect to family savings is approximately 0.31 , controlling for measures of students' college aptitude. Even among students who attend public colleges, this elasticity is $0.22 .{ }^{9}$

\subsection{Supply-Side Trends in Higher Education}

The most salient phenomenon on the supply side of higher education has been the real growth in college tuition. College tuition has risen faster than the consumer price index (CPI) over the entire post-World War II period. Figures 2 and 3 show the growth in college tuition and tuition revenue from 1970 to 1993 . Several explanations have been advanced for the rapid growth of tuition, especially that of private colleges. Ehrenberg and Murphy (1993) point out that need-based aid mechanistically accelerates growth in "list price" tuition. If a college that uses needbased aid wants to increase its tuition revenue at a certain rate, it must

\footnotetext{
${ }^{9}$ Author's calculations based on the National Postsecondary Student Aid Survey.
} 


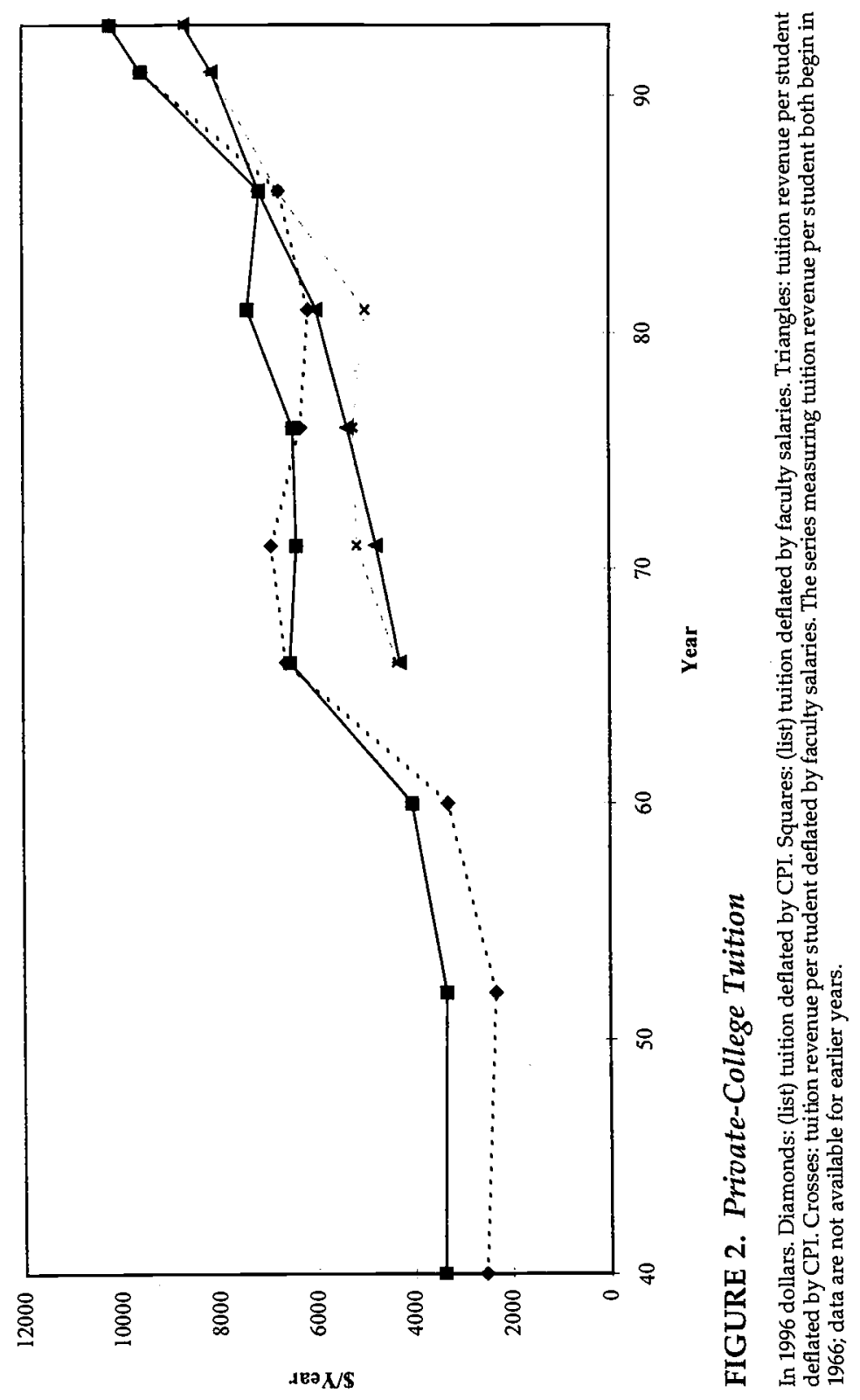




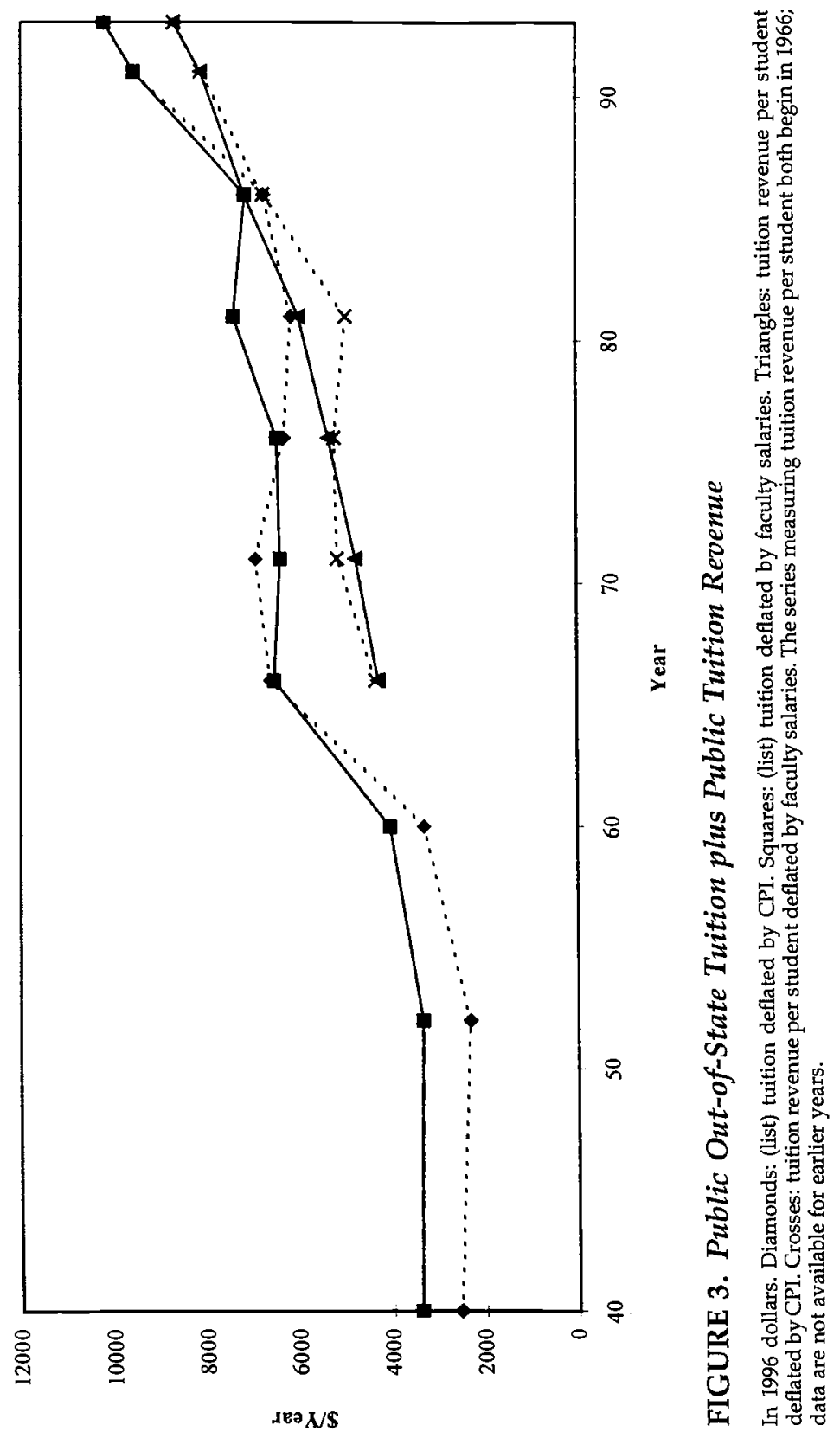


raise its list tuition at a higher rate because every increase in list tuition increases the financial aid it is committed to provide. The EhrenbergMurphy mechanism is a real phenomenon, but Figures 2 and 3 show that not just list tuition but also tuition revenue has grown rapidly.

Clotfelter (1996) suggests that the increased rate of return to higher education since 1978 has increased the demand for college and that colleges have raised tuition in consequence. His argument implicitly asserts that American colleges do not have elastic supply and do have market power that allows them to take rents. This explanation does not fit the data well. Four-year colleges' tuitions have grown much faster than those of two-year colleges, yet longitudinal surveys suggest that the total applicant pool for baccalaureate education has grown by just 10 percent since 1978. In contrast, the pool of applicants to two-year colleges has grown by 36 percent, and these colleges' tuitions have grown less than half as fast as those of four-year colleges. Moreover, sluggish salary growth for college faculty (which has significantly lagged behind that of other workers with post-baccalaureate education) suggests that colleges have not reached the inelastic portion of their supply curves.

The argument that colleges have market power conflicts with the evidence of Hoxby $(1997,1998)$, who shows that colleges have faced an increasingly integrated and competitive market over the post-World War II era. The typical student no longer automatically chooses a local college. To obtain its student body, the median college now competes in a market that spans almost 20 states as opposed to 5 states in 1950 (both numbers are smaller if colleges are enrollment-weighted). This information is summarized in Table 2. Hoxby suggests that the more integrated structure of the college market and improved information flows (better information for students about colleges and better information for colleges about students) have meant that colleges have experienced increase in competition and have lost monopoly and monopsony power. Colleges have responded to this loss of market power by differentiating themselves vertically (by specializing in a certain quality of student and level of admissions selectivity) and horizontally (by finding a market niche-for instance, serving local managers who wish to pursue an MBA in the evening). The differentiation response to market integration is intuitive. Also, market integration and loss of market power induce a decrease in colleges' ratio of tuition to the level of services they provide. However, the microeconomics of the market for college education are such that most of this decrease has occurred not through decreases in tuition, but through increases in the package of services (hereafter called "quality" for convenience, though it need not correspond to academic 


\section{TABLE 2}

The Increasing Geographic Integration of the Market for Baccalaureate College Education

\begin{tabular}{lccccc}
\hline & \multicolumn{5}{c}{ Percentage of students who attended college in state } \\
\cline { 2 - 6 } & 1949 & 1963 & 1968 & 1981 & 1994 \\
\hline All colleges & 93.2 & 85.1 & 82.9 & 77.3 & 74.5 \\
Private colleges & 80.0 & 68.2 & 65.6 & 62.0 & 54.6 \\
Public colleges & 95.6 & 90.8 & 90.1 & 89.7 & 84.0 \\
\hline
\end{tabular}

Percentage of baccalaureate-granting colleges that drew students from. . .

\begin{tabular}{lrrrrr}
\cline { 2 - 6 } & 1949 & 1963 & 1968 & 1981 & 1994 \\
\hline 40 or more states & 2.4 & 6.2 & 6.5 & 6.8 & 7.3 \\
20 or more states & 16.2 & 25.2 & 26.1 & 26.7 & 35.5 \\
\hline
\end{tabular}

Herfindahl indices for colleges,

showing concentration of their students'

states of residence

\begin{tabular}{lccccc}
\cline { 2 - 6 } & 1949 & 1963 & 1968 & 1981 & 1994 \\
\hline All colleges & 0.79 & 0.71 & 0.67 & 0.64 & 0.59 \\
Private colleges & 0.62 & 0.53 & 0.49 & 0.47 & 0.41 \\
Public colleges & 0.96 & 0.91 & 0.87 & 0.84 & 0.77
\end{tabular}

Note: Statistics calculated from a panel of 1,551 baccalaureate-granting colleges, taken from the Residence and Migration surveys. Colleges that do not grant baccalaureate degrees have negligible acrossstate market integration, except in metropolitan areas that happen to span state lines.

quality) provided by colleges. Indeed, market integration has given colleges so much incentive to raise quality that it has led to increases in the level of tuition (despite failing ratios of tuition to quality for many colleges), not merely increases in the dispersion of tuition.

In this paper, it is only possible to sketch the microeconomics of the market for college education and why integration led to increases in the level and dispersion of quality, rather than mere decreases in price. For simplicity, consider local college autarkies, each of which has a monopoly producer of college education. Geographic integration of the autarkies has pro-competitive effects because the former monopolists compete with one another for consumers. This reduces tuition-to-quality margins (price-cost margins) and benefits consumers (students). The former monopolists also compete with one another for inputs. This raises the wages of inputs, who include college workers but also college students. These results carry over to the more general case in which each local market begins with several college that may initially offer different 
levels of service quality (vertical differentiation) or different packages of services (horizontal differentiation).

Market integration tends to raise the level of service quality offered by the average college, and the increase in service quality can be dramatic for colleges that began with relatively good students and services. There are several reasons why this occurs. First, as autarkies integrate, colleges enjoy greater marginal returns to expenditure on quality improvements. The intuition is that, for a given increase in service quality, a college can attract many more students (consumers with higher demands). Second, there are a few features of college education that give it especially interesting microeconomics. The quality of a college is partly determined by the peers with whom a prospective student would be educated. Students, therefore, are inputs into the production of their particular college's education as well as consumers of it. Students who have high demand for quality education also tend to be high quality inputs. Rothschild and White (1995) demonstrate that, because students are consumers and inputs simultaneously, net tuition (tuition minus any institutional grants) combines the price that a student pays and the wage he is paid. In the simplest case, colleges might charge a list tuition for students whose input quality was minimal and offer scholarships (which rose with input quality) to all other students. More generally, colleges offer subsidies to students in many forms. Market integration increases the quality demands of high-demand, high-quality students because the "wages" that they can spend on college education rise with the loss on monopsony power. This implies that the quality of a college will rise more if it was initially a highquality college. Moreover, colleges that need to reduce their tuition-toquality margins when they face increased competition will generally do so by raising quality. The reason is that a college that makes an investment in quality will not just get the direct improvement in service quality, but will also get an indirect improvement in quality as better student peers are attracted. Conversely, a college that lowers its tuition-to-quality margin by lowering its tuition and holding service quality constant will attract new students, but the students will tend to have lower demand and therefore be lower-quality peers. The indirect effect will work against the college in this case.

In summary, theory predicts several reactions to increased integration and competition in the market for college education: ${ }^{10}$

${ }^{10}$ Market integration has also reduced the ability of states to offer highly subsidized public college tuitions. Students are increasingly able to arbitrage differences in different states' subsidies; middle-class parents are less enthusiastic about taxes to finance low "in-state" tuition as their children become more likely to attend college out of state; and public 
1. a loss of monopoly power for colleges, generating increased value for students as consumers;

2. a loss of monopsony power for colleges, generating higher subsidies for students whose quality (ability) is high;

3. an increase in average college quality because investments in quality earn higher returns;

4. an increase in average college tuition commensurate with the average quality increase;

5. increased sorting of students among colleges based on their demand for quality;

6. a larger increase in quality (and tuition) for colleges that were initially of high quality, owing to the fact that high-demand students have their demand boosted by the income effect of the loss of monopsony power;

7. unusual sustainability of quality competition compared to price competition, owing to the fact that the indirect peer effect favors quality competition;

8. increasing diversity among colleges along the lines of student ability, quality, tuition, and subsidies-whereby the same colleges that have the greatest increase in student ability have the greatest increase in quality, tuition, and subsidies.

The increase in competitiveness (or decrease in local market power) has not been evenly spread across colleges. In particular, two-year colleges continue to draw students from populations whose mobility is very limited because college is often combined with work or other responsibilities. In conditional logit equations that predict college choice, proximity has had a waning influence for baccalaureate students since 1970 at least, and immediate proximity (a 5-mile radius of the family home) has no statistically significant effect. For two-year students, the immediate proximity of a college is statistically significant, and the point estimates suggest that it is as important in a 1990 prediction of the college chosen as it was in 1970.11

The final supply-side explanation for the increase in tuition is the Bennett hypothesis, which argues that federal tuition subsidies (in the form of Pell grants, reduced interest on student loans, and work-study wages) have fueled tuition increases. For two reasons, the least selective part of the college market is where we are most likely to find empirically

colleges struggling to retain their past share of high-ability students can only do so by breaking the same-tuition-subsidy-for-all rule.

11 See Hoxby (1997). 
relevant increases in tuition driven by federal subsidies. First, as described above, less selective colleges are more likely to still enjoy local market power. Second, Pell grants and supplemental educational opportunity grants (SEOGs) account for 2.4 times as much federal expenditure as the Perkins loan and work-study programs combined. Pell grants and SEOGs are paid disproportionately to two-year colleges, which, though they enroll only 22 percent of American college students (measured in full-time equivalents), absorb 49 percent of the federal government's expenditures on the Pell and SEOG programs. Also, Pell and SEOG grants can fund a much larger share of a typical two-year college's tuition. The average Pell grant at a public, two-year college was about $\$ 1,400$ in 1995 , an amount which covers, on average, about two-thirds of two-year college tuition (or about 80 percent of two-year public college tuition). The average Pell grant at a private, four-year college was about $\$ 1,600$ in 1995, an amount which covers about one-fifth of tuition for the average such college.

We lack definitive evidence on the elasticity of tuition with respect to the Pell grant, but the best empirical methodology (from Li, 1997) is as follows. We want to estimate individual college's tuition reactions (if any) to exogenous changes in their opportunities to acquire Pell grant revenue. Because colleges differ tremendously in the packages and quality of the services they offer, it is important to use panel data that allow us to control for college-specific determinants of tuition. Because major changes in the Pell-grant formula (from which we must ultimately derive identification) do not occur every year, the minimum panel length is 1215 years ending with the current year. However, time series variation in the Pell-grant formula is an inadequate source of identification, particularly in an era in which higher education is simultaneously experiencing other sources of pressure on tuition. Owing to the fact that they serve different populations, different colleges experience very different revenue shocks when the Pell formula changes. For instance, a public twoyear college serving a low-income area might have 20 percent of its students using Pell grants. A two-year college in a middle-class, suburban area might have only 5 percent of its students using them. A private, selective, four-year college might have a negligible percentage of its students on the Pell grant. Therefore, it is reasonable to think that a Pellgrant recipient might be the marginal demander whose behavior sets tuition in the public two-year college located in the low-income area (assuming that the college has few institutional resources for giving tuition discounts). However, no economic model would suggest that a private, selective four-year college with the ability to use institutional resources to offer students a variety of "net tuitions" would have a Pell 
grant recipient as the marginal demander whose behavior sets the tuition. We could think of directly using the cross-sectional variation among colleges in the Pell-grant revenue attached to the marginal, tuition-setting student to identify the effect of federal grants on colleges' tuitions.

However, a number of estimation problems arise. The first is that we must estimate the probability that a college's tuition-setting student is a Pell-grant recipient. This is not only a function of the entire distribution of students in the college in a base year (knowing the characteristics of the average student is not sufficient), it is also a function of the college's control (public or private, since this affects the college's range of possible tuition-setting policies) and the college's resources (since they affect the college's ability to use institutional aid to price discriminate among students). Given this estimate, we must then predict the shock from the change in the Pell grant to the budget constraint of the students who are predicted to be tuition-setting (assuming that the college does not change its tuition). This prediction is created by feeding the characteristics of a college's marginal students through the old and new Pell grant formulae. Finally, we must use this predicted shock as an instrumental variable for the actual shock to the budget constraint of the students who are predicted to be tuition-setting. The intuition behind this empirical procedure is that the predicted shock should not include any observed changes in a college's population of students or the Pell grant of tuition setting students that are themselves a response to the college's changing tuition in the fact of an increased Pell grant.

$\mathrm{Li}$ (1997) carries out this empirical methodology using the universe of Pell-grant recipients' records and a large sample of all federal financial aid applicants. Her preliminary estimates, which should be interpreted cautiously, suggest that a $\$ 100$ increase in the per-student Pell grant revenue of a public two-year college generates a $\$ 17$ increase in tuition. Significant increases are not found for public four-year colleges or private four-year colleges, and the estimates for private two-year and proprietary two-year colleges are imprecise (because the number of these types of college is small, the preliminary estimates are unreliable). It is important to note that the predicted tuition increase for two-year colleges does not occur because every college raises its tuition. The $\$ 17$ represents the average reaction of colleges, some of which do have Pell grant recipients as tuition-setters and some of which do not. Eventually, it will be possible to estimate the reaction of a college that has a large minority of students on the Pell grant. Because it is easier for a college to choose the best tuition response when a high proportion of its students use the Pell grant, the tuition response will presumably be larger than $\$ 17$. 
A college's determination of the best tuition response is also complicated by the fact that the Pell grant is a highly nonlinear function of a student's background characteristics (family income, family wealth, family composition), so that even an extraordinary college that had every student on a Pell grant could not easily calculate the rise in list tuition that would absorb the Pell grant increase. Moreover, a college's best tuition response depends on the amount of competition it faces. In particular, a two-year college that retains significant local market power will be able to absorb more of the Pell grant increase without experiencing much reduction in enrollment.

\section{INCREASED PELL GRANTS IN THE 1998 BUDGET}

Given the above, the increase of the maximum Pell grant from $\$ 2,700$ to $\$ 3,000$ in the 1998 budget requires only a few sentences of additional analysis. The economic justification for Pell grants is clear. They give a means-based subsidy to a group of students who are so poor that they would otherwise likely be prevented by liquidity constraints from making their optimal investments in college education. The 1998 budget raises the Pell grant by more than 10 percent, and this would appear to be a large increase. Figure 4 shows, however, that the $\$ 3,000$ maximum will not make the real Pell grant high relative to history. Moreover, since college costs have been increasing faster than inflation, the Pell grant as a percentage of average college costs has been falling almost monotonically since the program's inception. This is shown in Figure 5. Since

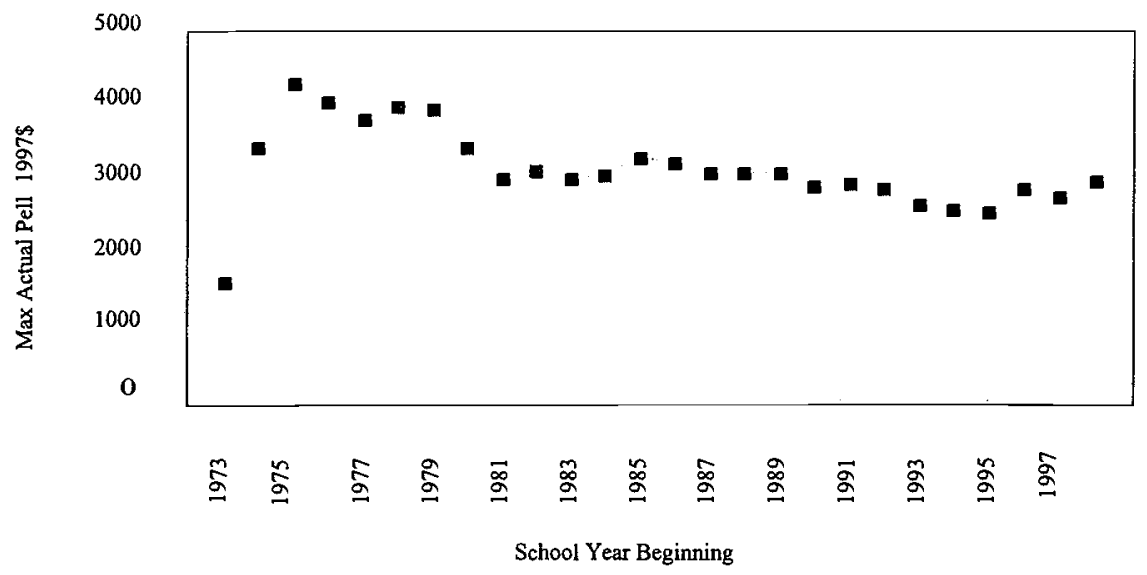

FIGURE 4. Maximum Actual Pell Grant, 1973-74 to 1998-99 


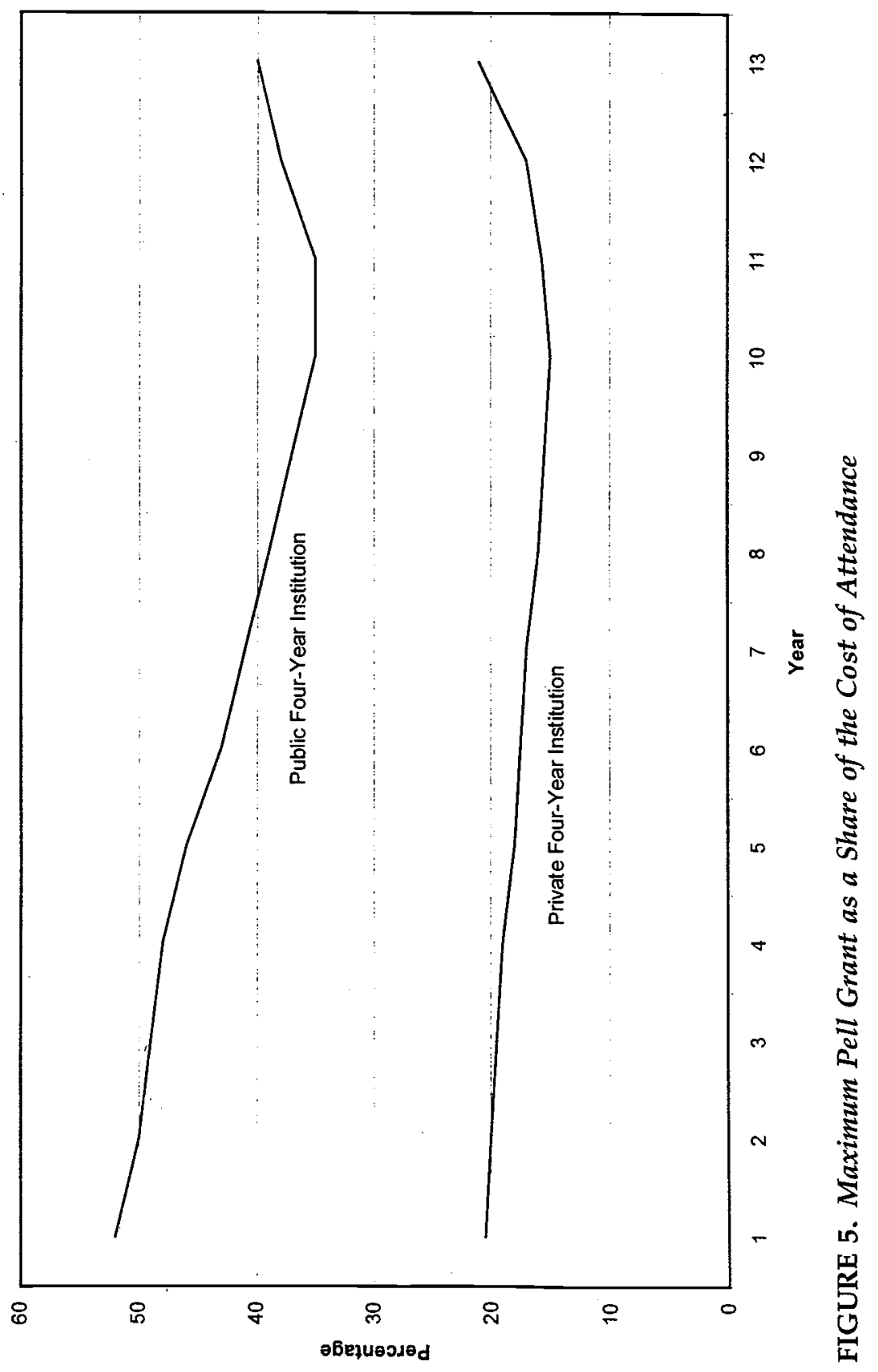


middle-class households are the main beneficiaries of the four tax provisions in the 1998 budget, an additional benefit of raising the Pell grant is that the increase will help to maintain the current degree of equality of educational opportunity between poor and middle-class households. The $\$ 3,000$ Pell grant may also help poor students cope with the tuition increases that are likely to occur in the wake of the two tax credits.

There are no major disadvantages to raising the Pell grant. Some grants may be wasted by students who do not take college seriously or may be rent for colleges that exploit naive students, but there is little reason to believe that the size of the increase will be sufficient to induce a significant increase in waste.

\section{PENALTY-FREE WITHDRAWALS FROM IRAS FOR COLLEGE EXPENSES AND TAX-SHELTERED COLLEGE SAVING ACCOUNTS}

The federal budgets from 1998 to 2002 are expected to contain $\$ 1.0$ billion for the new policy allowing penalty-free withdrawals from IRAs for college expenses and the creation of IRA-like college savings accounts (EIRAs). This estimate appears to be a long-run, equilibrium estimate (as though the policy existed in steady state) rather than an accurate prediction for the first few years of a new savings plan (into which people can easily transfer existing savings.) In the first few years of the policy, we should expect families' dynamic readjustment to produce a surge of withdrawals from IRAs and deposits to EIRAs. ${ }^{12}$

We expect the policy to work as follows. Each year, families with income lower than the phaseout range were or are able to make taxsheltered savings deposits for college expenses of up to $\$ 2,000$ per spouse in IRAs plus $\$ 500$ per child in EIRAs. IRAs from the era before the Tax Reform Act of 1997 are front-loaded, meaning that contributions are not included in gross income for tax purposes but are taxed when withdrawn.

12 The 1998 budget estimate of $\$ 1$ billion does not allow for dynamics. In 1998, families with a child in college will withdraw more money from IRAs than they would if the policy had always existed. Consider a family that would have liked to withdraw $\$ 1,000$ a year from an IRA for their child's college expenses had it been possible to do so without penalty. If the child will be a college senior in 1998 , the family might withdraw $\$ 4,000$ in a single year. On the other hand, people who already save for future college expenses will immediately transfer the first $\$ 500$ per child of their accumulated savings into tax-sheltered CSAs. But many more families will have a stock of savings equal to $\$ 500$ per child in 1998 than will have a yearly flow of new savings of $\$ 500$ per child, even with the new incentives to save. The bulge of IRA withdrawals in 1998 will add tax revenue, but the bulge of transfers to CSAs will remove tax revenue. One can form a reasonably good prediction of the latter effect, but predicting the former effect with any accuracy is nearly impossible. 
EIRAs and current IRAs are back-loaded, meaning that contributions are taxed in the year of contribution but not thereafter. The income in all IRA/ EIRAs compounds tax-free, and no penalty is due on distributions from IRA/EIRAs that are used to pay for college expenses. Table 3 and its notes demonstrate that IRA/EIRAs are an advantageous means of saving for college expenses, compared to regular savings accounts. One of the examples in Table 3 shows that the maximum that can possibly be accumulated for a child's college expenses in IRA/EIRAs is about $\$ 109,000$ in 1997 dollars. This accumulation assumes two parents who have only one child, who make the maximum contribution for each member of the family each year that the child is under age 19, and who earn a 3-percent real rate of return on their savings. Another example in Table 3 shows that an annual EIRA contribution as small as $\$ 200$ will provide a student with about $\$ 4,800$ in 1997 dollars. Such a sum would be very useful: it would pay for one year's tuition at a typical public college and for an Associates Degree at most two-year colleges. A good rule of thumb is that the money needed to achieve any given accumulation with a regular savings account is about 1.1 times the money needed with $\mathbb{R A} /$ EIRAs. In short, the availability of IRA/EIRAs substantially increases the average return to college saving. A family's marginal rate of return to college saving will increase if the amount $(\$ 2,000 \times$ no. of spouses $)+(\$ 500 \times$ no. of children $)$ is larger than what its annual flow of new college saving would be in the absence of IRA/EIRAs.

There are several potential benefits from the IRA/EIRA program. The first is an increase in savings among families who experience an increase in the marginal rate of return to saving. ${ }^{13}$ Many economists ${ }^{14}$ have argued that America's savings rate is unduly depressed by capital taxation and the social security program and that the low savings rate depresses economic growth. The second benefit of the IRA/EIRA program is that it will partially offset the tax on savings due to need-based aid. A third benefit occurs because a number of states already have tax-sheltered savings accounts that families can use for the expenses of certain in-state colleges. The restriction that a student must attend college in state is becoming more confining every year because inter-state mobility of college students has been increasing steadily since 1940, as shown in Table 2 . Inter-state mobility is especially important for students whose achievement is high enough to earn admission to selective colleges-exactly those students

13 A family must not only experience an increase in its marginal return to college saving, it must also be on the margin of saving for college. A family whose entire saving is dedicated to retirement expenses, for instance, will not experience an increase in its marginal return to savings.

14 See Sandmo (1985) for reviews of this literature. 


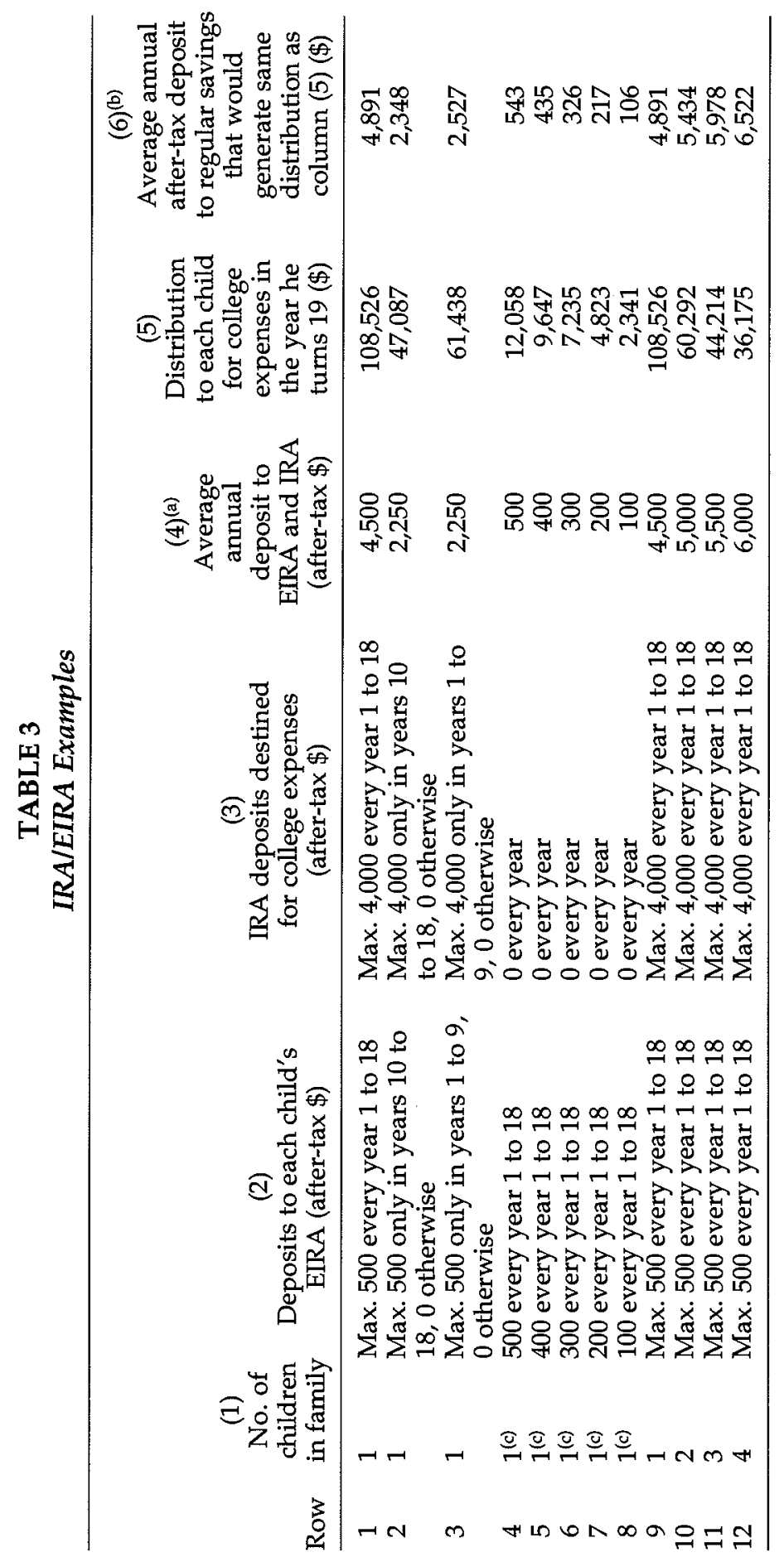




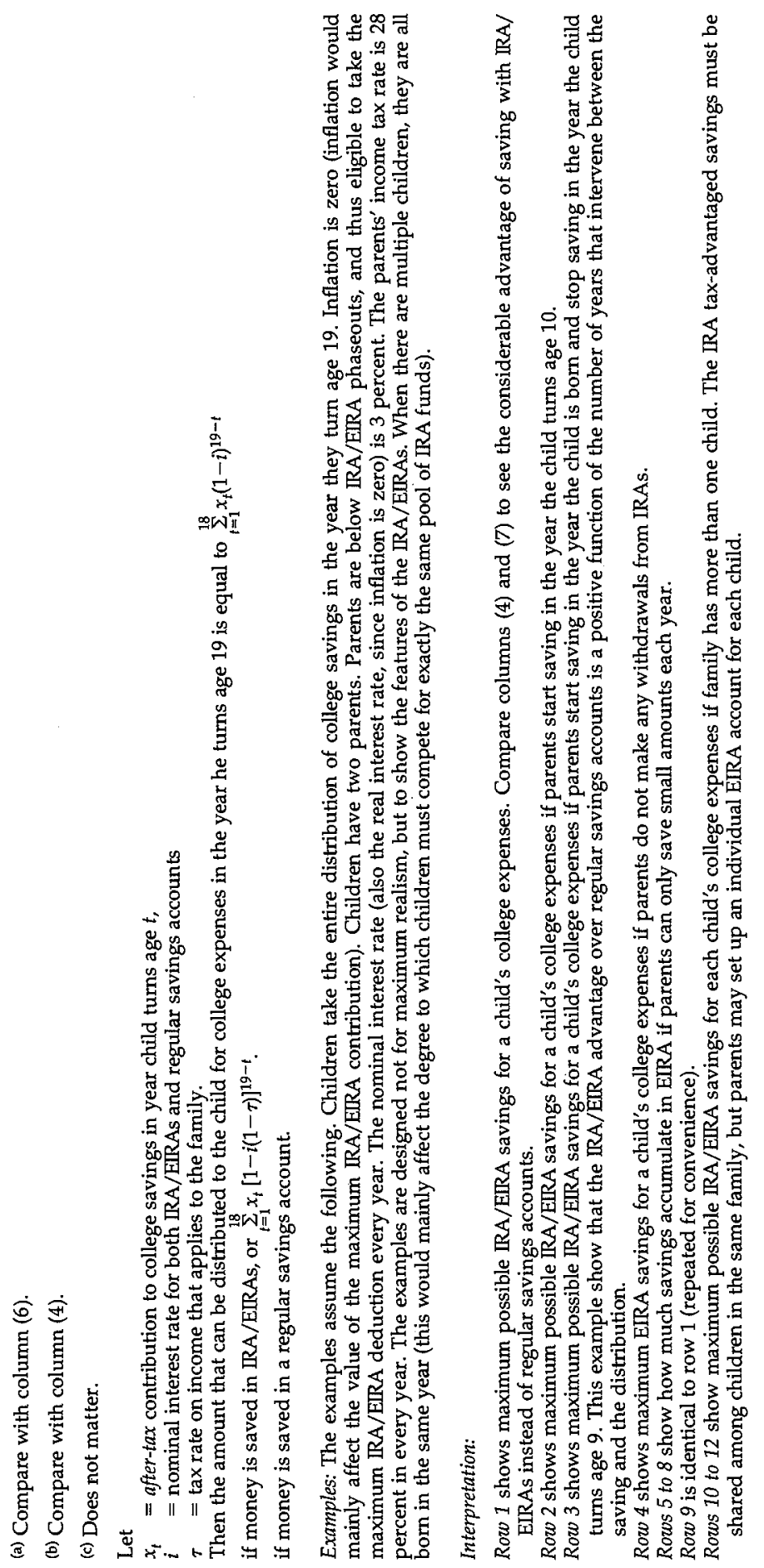


for whom forward-looking college saving is most important. Thus, state tax-sheltered accounts unintentionally constrain students to make lessthan-optimal college choices and disfavor college savings for high-ability students. IRA/ERAs will eliminate these between-student distortions because they are attractive enough to supersede most state programs. ${ }^{15}$

The most important potential benefit of IRA/EIRAs comes from the fact that they offset some of the capital market failures for human capital investments. Because human capital investments are not collateralizable and because a person's investment in human capital is undiversifiable (he can only invest in his own human capital), there are numerous failures in the financing of an investment in college education. For this reason, many students rely on parental savings. But there are reasons why parents may not perceive a high enough return to saving for their children's college expenses. Parents do not receive direct benefits of their children's college education, and they do not have a method of ensuring indirect benefits through repayment with interest. Their children may give too little back to them, or their children may give similar amounts rather than the amounts that would equalize the marginal return to parents' saving. Even if the parents could obtain repayment under most circumstances, they might choose not to have so many assets tied up in undiversified investments. For all these reasons, investment in college education is likely to be lower than optimal. By subsidizing the return to college savings, IRA/EIRAs would be a countervailing force that would move human capital investment closer to the optimum.

Another important benefit of the IRA/EIRAs is that, by encouraging families to put savings into accounts dedicated to college expenses, they will make families think about college education earlier and with greater commitment. It appears that there is an educational advantage to early commitment. Students make more optimal college decisions and more effort in secondary school when they are interested early on in preparing to attend college. As Owen (1995) notes, much of students' failure to prepare well for college while in secondary school comes from the remoteness of the college choice decision. By establishing a college savings account, a student is forced to think more concretely about the return to college education. Thaler's (1990) work on mental accounts provides a

15 If a student knows exactly which college he wishes to attend long in advance and the tuition that his parents will pay is systemically rising faster than inflation, they may also benefit from plans that allow them to pre-pay tuition. The plans generally restrict future college choice severely. In addition, some parents use the plans as insurance against a risk they do not face. Parents pay too much attention to how fast the list price of tuition is rising, and not enough attention to how fast the tuition net of financial aid that they would pay is rising. 
theoretical basis for the observation that students become significantly more interested in future college attendance if they stand to suffer a penalty from transferring savings from college expenses to other uses.

Unfortunately, IRA/EIRAs provide little help to students who have parents who are prevented from saving by liquidity constraints or who lack foresight. Also, the current IRA/EIRA phase out region is rather low if we want the tax shelter to offset the "tax" on college savings generated by need-based aid. Of the families most likely to distort their consumption and asset choices to avoid the "tax" (families of students who attend selective private colleges that offer substantial amounts of institutional, need-based aid), 21 percent have household incomes greater than $\$ 150,000$. In general, institutional need-based aid calculations will spread some of the benefits of IRA/EIRA saving to families that choose not to save.

\section{THE DEDUCTION FOR INTEREST ON STUDENT LOANS}

IRA/EIRAs only generate more optimal human capital investments for students whose parents are able or willing to save for college expenses. For students who do not receive a sufficient boost to their incentives through this channel, the 1998 through 2002 budgets contain approximately $\$ 1$ billion for the deducting the interest paid on student loans. In 1998 , an individual can deduct from his taxable income up to $\$ 1,000$ of interest he paid during the year. By 2001, the maximum deduction will have risen to $\$ 2,500$. An individual need not itemize to take the deduction. If the deduction is taken, then the effective interest rate is $i(1-\tau)$ where $i$ is the statutory rate and $\tau$ is the income tax rate that applies to the borrower.

The major economic benefit of the tax deduction is that it can make human-capital investments more optimal by subsidizing the cost of borrowing to finance such investments. Market failures for investments in human capital tend to make students require a rate of return to investments in human capital that is excessive relative to that which is socially optimal. The main causes of failure in the market for student loans is that a student's investment in his human capital is non-collateralizable and non-diversifiable. Being risk-averse, students require a rate of return on the investment that is higher than the average rate of return to other economic investments. The deductibility of interest on student loans reduces students' required rate of return and thus is likely to move human capital investment towards the social optimum. 
A minor benefit of the deduction for interest on student loans may be an increase in repayment compliance. Compliance is a serious problem for federally guaranteed student loans (the default rate is 9.9 percent on average). ${ }^{16}$ In any year, there are individuals on the margin of complying because their costs of compliance (payments) are not much smaller than their costs of non-compliance (the expected value of penalties). The deductibility of interest might induce a few people to comply who would otherwise be out of compliance. This would decrease the federal government's cost of guaranteeing student loans.

Unfortunately, the deductibility of interest on student loans discourages college savings because it lowers the price of financing through loans relative to financing through saving. For the same reason that the policy "insures" students against the accident of having parents who are unable or unwilling to save, the policy discourages saving.

The 1998 budget unduly constrains the use of the deduction. The policy starts out with maximum deduction $(\$ 1,000)$ that is so small that the marginal rate of interest for approximately 20 percent of students will not change. Additional constraints are imposed by the fact that the maximum deduction is per household, not per student. The constraints on the use of this policy are unfortunate because lowering the cost of borrowing for a college education is one of the simplest ways of remedying capital-market failures for investments in human capital.

\section{GENERAL NOTES ON THE DIFFERENCE BETWEEN POLICIES THAT SUBSIDIZE A FAMILY'S USE OF THE CAPITAL MARKET FOR COLLEGE EXPENSES AND POLICIES THAT SUBSIDIZE THE PRICE OF COLLEGE}

The previous two policies work by lowering the "hurdle" rate of return that an investment in college education must earn. They can be justified by appealing to obvious failures in the capital market for human-capital investment. The policies intervene in the capital market-by raising the return to savings for college investments and lowering the cost of borrowing for college investments. The subsidy received is a function of a student's use of the capital market. Note that nowhere along the way have I had to invoke the argument that investments in college are a public good. That argument is troublesome because even if we believe $a$ priori that some public returns exist, we have no way of quantifying

${ }^{16}$ See U.S. General Accounting Office (1997) and Miles and Zimmerman (1997) for recent evidence on the student loan program. 
them adequately to calculate appropriate subsidies. In addition, it is unsatisfactory because both the formation of firms and the formation of neighborhoods contain mechanisms that internalize many of the externalities associated with being around college-educated people.

The Tax Credit for Lifelong Learning and Hope Credit do not have the two desirable properties mentioned above. First, if they are to be justified as education policies (likely to induce more optimal investments in education) and not just as tax cuts, then we must invoke the argument that investments in college are a public good. Second, the fact that the tax subsidies are simple functions of the tuition that a student pays almost invites real tuition increases. While these tuition increases are likely to be balanced by quality increases among colleges that face a large amount of competition from other colleges, colleges that do not face much competition because their students are constrained by location may simply raise price.

\section{THE TAX CREDIT FOR LIFELONG LEARNING}

The Tax Credit for Lifelong Learning (TCLL) is by far the most expensive policy I have considered thus far. For each undergraduate or graduate student, the TCLL can give a tax credit equal to 20 percent of the amount (up to $\$ 5,000$ ) he spends on tuition and fees. The maximum amount rises to $\$ 10,000$ after 2002. Note that (at least until 2003) students should always elect to use the Hope Credit over the TCLL if they are eligible for both, since the Hope Credit will always be more generous.

The TCLL is a good education policy if the difference between the social and private returns to college is large enough to justify the size of the subsidy. If a public return exists, then we can induce more optimal investments in human capital either by subsidizing use of the capital market for college (IRA/EIRAs or tax deductions for interest on student loans) or by subsidizing the price of college (as in the TCLL). That is, arguments based on social returns exceeding private returns do not imply that price subsidies are better than capital market subsidies, but arguments based on capital-market failures do imply that capital market subsidies are better than price subsidies. Therefore, if we are to justify price subsidies, we must invoke a social return argument. In the case of the TCLL, if the first $\$ 5,000$ of college expenditure each year $(\$ 10,000$ after 2002) earns a social return that exceeds its private return by an amount approximately equal to the market rate of return, then the policy will induce students to make human capital investments that are socially optimal.

We might also analyze the TCLL purely as a tax cut for middle-class 
taxpayers. The tax cut is distributed according to the amount of tuition a family pays for college, not according to its income or the amount of tax it pays. This creates divergent tax rates between households that, for instance, are the same except that their children attend colleges with different tuitions. ${ }^{17}$ Such divergence can be justified with the argument that higher education earns public returns, but then we are back to needing to justify the TCLL as an education policy, not as a middle class tax cut. Moreover, the TCLL is not a general middle class tax cut, because it is highly age-specific and thus applies to only about 8 percent of Americans each year. Thus, the creation and possible future destruction of the TCLL can produce significant inter-cohort inequalities in taxation.

A more disturbing problem for the TCLL as a tax cut is that some of tax credit may end up in hands other than those of the intended recipients, middle-class taxpayers. If the TCLL generates increases in college tuition, then the families who receive the credit will get smaller increases in income than the TCLL appears to grant them. Our best evidence on the elasticity of tuition with respect to tuition subsidies comes from the last ten years' changes in the Pell grant (Turner, 1997; Li, 1997). However, we do not have direct evidence on the tuition consequences of tuition subsidies that are as large and ubiquitous as the TCLL. Li's estimate of $\$ 17$ of increased tuition per $\$ 100$ of increased Pell grant should be adjusted upwards before being applied to the TCLL because it is significantly harder for a college to calculate the non-competitive tuition response for a Pell-grant increase than for the TCLL. The TCLL will be much more ubiquitous than the Pell grant, which involves only a small minority of students at most colleges. Fewer than 2 percent of American colleges have more than 40 percent of their students on the Pell grant. In contrast, nearly every college in the United States that has undergraduate juniors, seniors, or graduate students will have the TCLL apply to more than 90 percent of these students on average.

The second reason is that the TCLL is a simple function of the tuition that a student pays, whereas the Pell grant is a highly nonlinear function. While the non-competitive tuition response to the Pell grant would involve complex calculations and price discrimination, the non-competitive tuition response to the TCLL would be an across-the-board tuition in-

${ }^{17}$ The second sort of horizontal inequity is particularly troubling if it arises because the households are in states that have different policies about public-college tuition. If a household has paid additional taxes over a long period of time so that its public colleges (which cost the same amount as other states' colleges to run, say) can charge minimal tuition, it is not reasonable to penalize the household by giving it a smaller tax credit. Also note that the fact that the credit is non-refundable may create horizontal inequities among families who are identical except their children are differently spaced. A family with multiple children in college simultaneously is more likely to be constrained by non-refundability. 
crease approximately equal to 20 percent of tuition up to $\$ 5,000(\$ 10,000$ after 2002). Colleges that face immobile student bodies should be able to raise their tuitions by a high proportion of the TCLL-more than $\$ 17$ for every $\$ 100$ of subsidy. Fortunately, colleges that have substantial local market power tend to have small programs or no programs for upperdivision undergraduates and graduate students. Among colleges that face the integrated market, a college that absorbed much of the TCLL without commensurate quality increases would lose students to its competition. Thus, we should expect selective colleges to raise tuition by a fraction of the TCLL ( $\$ 17$ per $\$ 100$ is a reasonable first approximation) and to raise quality commensurately.

Because the TCLL only gives a credit equal to 20 percent of tuition and fees that a family pays, families are still responsible for the majority of tuition. Therefore, the TCLL is not likely to induce students to enroll in college for reasons that are more recreational than educational. Also, students will still have plenty of incentive to make effort so that they may earn a private earnings return on college education that is approximately a market rate of return.

\section{THE HOPE CREDIT}

The Hope Credit applies to the first two years of college. It offers students a tax credit equal to 100 percent of the first $\$ 1,000$ they spend on tuition and fees in a year, and 50 percent of the second $\$ 1,000$. The Hope Credit is expected to cost the federal government even more than the TCLL, so it is the most expensive of the higher-education provisions.

Several of the Hope Credit's potential benefits and costs are similar to those of the TCLL. It can be justified as an education policy and a sensible distribution of a tax cut if the first $\$ 1,000$ plus 50 percent of the next $\$ 1,000$ earns a social return that exceeds the private return by an amount equal to the market return on capital. It may be easier to convince people of this argument than to convince people of the parallel one for the TCLL. This is because there is a widespread belief that ratio of social to private benefits is higher for lower levels of education.

Clinton's initial vision of the Hope Credit suggested that the 13th and 14th years of school could be made "universal" because the credit would make community college free or nearly free. The Hope Credit's first problem arises precisely because of this vision. As discussed, community-college education has grown faster than any other type of college education since 1978 , but is rarely used as a port of entry for ultimate completion of a baccalaureate degree. Community colleges are successful and cheap providers of remedial secondary-school educa- 
tion, and a year of community college education earns a rate of return roughly equal to the rate of return earned on a year of baccalaureate education (Kane and Rouse, 1995).

Unfortunately, the fact that community colleges provide a worthwhile service does not imply that it is good policy to make them nearly free and nearly universal. It is precisely because community college is not free and not universal that it succeeds with students who often have little to show for their secondary schooling. Many students who graduate from secondary school evidently do not take it seriously; longitudinal data on achievement tests indicate that the students' rate of learning slows substantially after the 8th grade, and 17 percent of students do not evince any statistically significant learning after the 8 th grade. Such students have, on average, over $\$ 6,500$ a year spent on their secondary-school education, yet-because the money is not theirs-it is unusual to find a student who is troubled by having wasted a good part of $\$ 26,000$ over the course of secondary school. When the same students enroll in community college, they are much more motivated. The amount of money ( $\$ 1,650$ is average tuition) they are investing is small relative to more than $\$ 6,500$ for an average year of secondary school, but it is sufficiently large relative to their incomes to make them zealous about earning a return. Also, the near-universality of high school diplomas has made them into uninformative signals to employers (Owen, 1995). ${ }^{18} \mathrm{~A}$ highschool graduate who wants to signal that he is more job-ready, skilled, and motivated than his peers can currently use college course taking as a classic Spence (1974) method of signaling. However, signals only work in equilibrium if there are sufficient cost or learning hurdles to deter those who lack skills, motivation, and job readiness. If the 13th and 14th years of education become nearly free and universal, individuals may find it necessary to engage in a 15th year of education in order to signal. the same degree of job readiness that they currently signal with only 13 years. In summary, if the Hope Credit were to succeed in making community college nearly universal, it would probably do so at the cost of making community college students less motivated and making the community college degree less rewarded.

The second disadvantage of the Hope Credit is that its current structure invites abuse. So long as they maintain half-time enrollment, students will be able to take up to $\$ 1,000$ of college courses free. Half-time status for $\$ 1,000$ is possible in most community colleges, and students

${ }^{18}$ They do signal that an individual does not have the serious disorders that lead to dropping out of high school. This is why the GED earns a return despite the fact that the typical GED recipient learns very little in preparing for the test. See Murnane, Tyler, and Willett (1997) and Cameron and Heckman (1997). 
will be able to enroll full time in most community colleges for just $\$ 200$ to $\$ 500$ a year. The contributions that the students themselves must make are so small that some of the students who enroll in response to the Hope Credit will not be primarily seeking education, but the package of recreation, job placement services, sports facilities, and access to inexpensive health care that colleges provide. Moreover, the rule that students must be in their first or second year of college will be unenforceable for a number of years. There is no registry of individuals' college degrees in the United States, nor do data exist that would allow the federal government to make such a registry. Colleges can require an applicant's high school record, but they have no way of insuring that "first- and second-year students" (those in their first or second year at the particular college) have not already completed college. Indeed, Lalonde, Jacobson, and Sullivan (1997) indicate that a substantial minority of community college course takers already hold baccalaureate degrees. There is nothing wrong with college graduates returning to community college or other introductory college programs if they are doing it in order to improve their earnings, but it is not the intention of the policy to provide college graduates with additional schooling or recreational opportunities at taxpayer expense. The Internal Revenue Service can do no more than guarantee that only two years of Hope Credit are claimed for any one social security number.

The most serious problem with the Hope Credit is that it encourages colleges to raise tuition. Many colleges in the United States will have nearly every first- and second-year student receiving a tax credit of exactly $\$ 1,500$, so colleges should have no difficulty coordinating the non-competitive tuition response. Tuition increases should be expected especially from two-year colleges, because they often have local market power and they only enroll first- and second-year students (allowing them to raise tuition across the board, instead of via complex price discrimination). We cannot get a precise prediction for the effect of the Hope Credit on tuition, but among two-year colleges and other colleges that enroll students from a very local population, all the information we have suggests that $\$ 17$ for every $\$ 100$ would be a serious underestimate. Perhaps $\$ 25$ out of every $\$ 100$ of the tax cut are likely to be absorbed by tuition increases.

\section{SUMMING UP}

When we consider all of the programs together, two conclusions stand out. First, a small share of federal resources are allocated to the highereducation initiatives that have the best properties as education policies. 
Second, the higher-education tax credits are an inefficient means of distributing middle-class tax cuts, especially if a substantial share of the Hope Credit is absorbed by tuition increases.

The rule that prevents households from using more than one of the four tax provisions for higher education in the same year is poorly constructed. It is reasonable to allow a student to take only the Hope Credit or the TCLL. However, by preventing students from taking Hope Credits or TCLLs in the same year that they take distributions from EIRAs, the federal government is imposing another implicit tax on college savings. Conflict may also arise between deducting interest paid on a student's undergraduate loans and taking the TCLL for graduate education. There is no economic rationale for preventing students from using these two benefits simultaneously.

Finally, empirical education research suggests that the IRA/EIRA program has long-term benefits that are hard to quantify but ultimately very important. The most powerful variables in explaining the earnings return that a student gets from a year of education are usually variables that indicate a family's concern and planfulness about education. If IRA/ EIRAs help families set up mental accounts for their children's college education, then they may motivate students to make more of the learning opportunities they currently have-especially since American education is already the most expensive in the world.

\section{REFERENCES}

Breneman, D. (1997). "Rethinking Saving Incentives." Forthcoming in A. Auerbach (ed.). Fiscal Policy: Lessons from Economic Research. Cambridge: MIT Press.

Cameron, S. and J. Heckman (1997). "The Dynamics of Educational Attainment for Blacks Hispanics and Whites." Columbia University and the University of Chicago. Mimeo.

Clotfelter, C. (1996). Buying the Best: Cost Escalation in Elite Higher Education. Princeton: Princeton University Press.

Dick, A., and A. Edlin (1997). "The Implicit Taxes from College Financial Aid." Journal of Public Economics. Forthcoming.

Dick, A., A. Edlin and Eric Emch (1997). "The Savings Disincentive of College Financial Aid." University of California, Berkeley. Mimeo.

Edlin, A. (1993). "Is College Financial Aid Equitable and Efficient?" Journal of Economic Perspectives 7(2):143-158.

Ehrenberg, R., and S. Murphy (1993). "What Price Diversity? The Death of Need Based Financial Aid at Selective Private Colleges and Universities." Typescript of an article that was published (shortened) in Change.

Feldstein, M. (1995). "College Scholarship Rules and Private Saving." American Economic Review 85(3):552-566.

Hoxby, C. (1997). "How the Changing Market Structure of American College Education Explains Tuition." NBER Working Paper no. 6323. 
1998. "The Changing Market Structure of U.S. Higher Education: 1920 to the Present." NBER Working Paper no. forthcoming.

Juhn, C., K. Murphy, and B. Pierce (1993). "Wage Inequality and the Rise in the Returns to Skill." Journal of Political Economy 101(3):410-442.

Kane, T. (1997). "Beyond Tax Relief: Long-Term Challenges in Financing Higher Education." National Tax Journal 335-349.

-, and C. Rouse. (1995). "Labor Market Returns to 2- and 4- Year College." American Economic Review 85(3).

Katz, L., and K. Murphy (1992). "Changes in Relative Wages, 1963-87: Supply and Demand Factors." Quarterly Journal of Economics 107(1):35-78.

Kim, Taejong (1997). "College Financial Aid and Family Saving." Cambridge, MA: MIT. Ph.D. Dissertation.

Lalonde, R., L. Jacobson, and D. Sullivan (1997). "The Returns from Community College Schooling for Displaced Workers." Michigan State University, Lansing, Michigan. Mimeo.

Li, J. (1997). "Do Increases in the Pell Grant Cause Colleges To Raise Tuition? A Test of the Bennett Hypothesis." Cambridge, MA: Harvard University. Typescript.

Miles, B. and D. Zimmerman (1997). "Reducing Costs and Improving Efficiency in the Student Loan Program." National Tax Journal 50(3):541-56.

Murnane, R., J. Tyler, and J. Willet. (1997) "Estimating the Impact of the GED on the Earnings of Young Drop-outs Using a Series of Natural Experiments," Harvard University Graduate School of Education. Mimeo.

Murnane, R., J. Willett, and F. Levy (1995). "The Growing Importance of Cognitive Skills in Wage Determination." Review of Economics and Statistics 77(2): 251-266.

National Center for Education Statistics (1996). "Postsecondary Education." In Digest of Educational Statistics, 1996. Washington: U.S. Government Printing Office.

Owen, J. (1995). Why Our Kids Don't Study: An Economist's Perspective. Baltimore: John Hopkins University Press.

Rothschild, M., and L. White (1995). "The Analytics of the Pricing of Higher Education and Other Services in Which the Customers are Inputs." Journal of Political Economy 103(3):573-586.

Sandmo, A. (1985) "The Effects of Taxation on Savings and Risk Taking." In Handbook of Public Economics, Vol. 1, A. Auerbach and M. Feldstein (eds.). Amsterdam: North-Holland.

Spence, M. (1974) "Education as a Signal." In Market Signalling, Chapter 2. Cambridge: Harvard University Press.

Taber, C. (1995). "Three Essays on Semiparametric Models of Dynamic Discrete Choice Program Evaluation and the College Premium in the Eighties." The University of Chicago. Ph.D. Dissertation.

Thaler, R. (1990) "Saving, Fungibility and Mental Accounts," Journal of Economic Perspectives pp. 193-205

Turner, S. (1997). Does Federal Aid Affect College Costs? Evidence from the Pell Program." Curry School of Education, University of Virginia. Typescript.

U.S. General Accounting Office (1997). Student Loans: Default Rates. Washington: U.S. Government Printing Office. 
